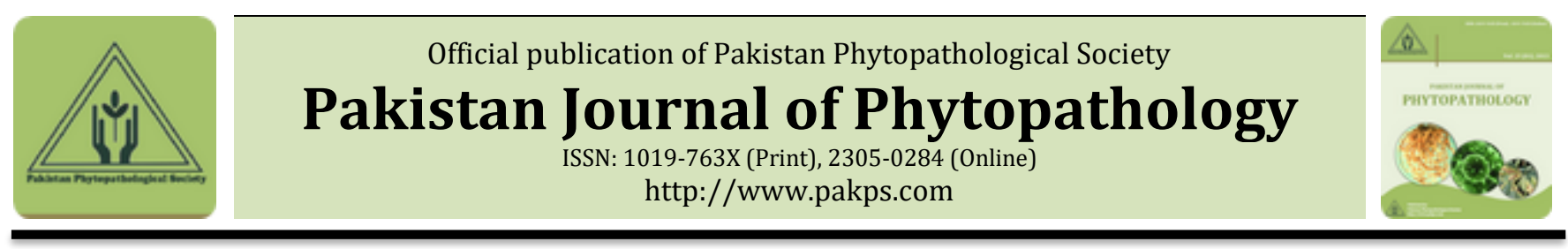

\title{
EFFECT OF ENVIRONMENTAL FACTORS ON BIOCHEMICAL PROPERTIES OF TOMATO LEAF CURL VIRUS INFECTED LEAVES OF TOMATO
}

\author{
aSaneela Arooj, aYasir Iftikhar, a\&BMustansar Mubeen*, cMuhammad I. Ullah, aAshara Sajid, dSaif Ali, \\ eQaiser Shakeel, fMuhammad Aatif, aWaqas Raza, gljaz R. Noorka, hHalima Qudsia \\ a Department of Plant Pathology, College of Agriculture, University of Sargodha, Sargodha-40100, Pakistan. \\ ${ }^{b}$ State Key Laboratory of Agricultural Microbiology and Provincial Key Laboratory of Plant Pathology of Hubei Province, \\ College of Plant Science and Technology, Huazhong Agricultural University, Wuhan 430070, Hubei, P.R. China. \\ 'Department of Entomology, College of Agriculture, University of Sargodha, Sargodha-40100, Pakistan. \\ ${ }^{d}$ MOA Key Laboratory of Crop Ecophysiology and Farming System in Middle Reaches of the Yangtze River, College of Plant \\ Science and Technology, Huazhong Agricultural University, Wuhan 430070, Hubei, P.R. China. \\ ${ }^{e}$ Discipline of Plant Pathology, University College of Agriculture and Environmental Sciences, The Islamia University of \\ Bahawalpur, Pakistan. \\ fCollege of Agriculture, BZU Bahadur Sub Campus, Layyah-31200, Pakistan. \\ gDepartment of Plant Breeding and Genetics, College of Agriculture, University of Sargodha, Sargodha-40100, Pakistan. \\ ${ }^{h}$ Research Officer (Plant Pathology), Rice Research Institute Kala Shah Kaku, Pakistan.
}

\begin{abstract}
A B S T R A C T
Tomato is a commodity of great economic importance in the world. One of the destructive viral diseases known as Tomato leaf curl virus belongs to Begomovirus has negatively impacted on tomato production in world. Tomato leaf curl virus widely distributed in the tomato crop and transmitted through whitefly in nature. Virus duplicates inside the host and altered various biochemical and physiological process. In this project, it was observed that the photosynthesis rate had positive correlation while lycopene and starch content (max temp) were negatively correled in relation to environmental variables when compared with healthy plants. In case of phenolic compounds, it was increased as temperature increased and vice versa. There is no effect of relative humidity on chlorophyll contents in infected plants.
\end{abstract}

Keywords: Temperature, vector, importance, phenolic compounds.

\section{INTRODUCTION}

Tomato is one of the most extensively grown vegetable across the world having potential health benefits. Lycopene present in tomato is one of the unique phytochemicals which provides protection against oxidative damage that lead towards slowing down the ageing process in plant (Agarwal and Rao, 2000). Due to perennial growth on a large scale; tomato is susceptible to various biotic and abiotic

Submitted: April 04,2019

Revised: May 05, 2019

Accepted for Publication: May 8,2019

* Corresponding Author:

Email: mustansar01@yahoo.com

(C) 2017 Pak. J. Phytopathol. All rights reserved. factors which adversely affect the plant growth, crop yield, different biochemical changes and physiological processes in plants (Hasegawa et al., 2000; Tajul, 2011). Viruses are serious threat among biotic factors which causes substantial yield losses both qualitatively and quantitatively. Almost seven viral diseases have been reported in Pakistan (Mughal, 1985). Among these viruses tomato leaf curl virus belongs to genus Begomovirus, single-stranded-DNA (Gottlieb et al., 2010; Hanssen et al., 2010) is most destructive virus that causes heavy yield losses up to $30-40 \%$ (Tariq, 1999). Tomato leaf curl virus infected tomatoes both in field conditions and greenhouses (Green, 1994). It is naturally transmitted through different species of whitefly and mechanically as well. 
The most obvious and characteristics symptom is distortion and upward curling of the leaves (Melzer, 2010). Wobbes (2004) described that biochemical changes due to viral diseases affect the normal physiological functions and directly involved in photosynthesis inhibition that may also be due to suppression of genes. Hemida (2005) observed the chlorophyll degradation in infected plants after the attack of TLCV. Epidemiological factors play a very significant role in development and spread of the disease (Mubeen et al., 2017). Although this disease has been reported in Pakistan but very little work and inadequate information is available on TLCV in Pakistan. Therefore, this experiment was designed to observe the impact of tomato leaf curl virus on physiological functions of tomato plants in relation to various environmental factors.

\section{MATERIALS AND METHODS}

Plant materials: The samples were collected from infected field and healthy samples from the previous trail (Arooj et al., 2017). Healthy and diseased leaves of tomato were collected for the estimation of chlorophyll, photosynthetic rate, starch, lycopene and phenolic contents in relation to environmental factors.

Estimation of Chlorophyll: Leaves (infected and healthy) were collected and washed with sterilized water. Chlorophyll contents in TLCV were compared using chlorophyll meter (SPAD-502 Minolta, Japan).

Estimation of Photosynthetic rate: Change in photosynthetic activity of leaves due to TLCV in both infected and healthy leaves was compared through portable photosynthesis appratus (IRGA).

Estimation of Lycopene: Lycopene contents were determined through the method purposed by Ranganna (1979). The tomato pulp from infected and healthy samples was extracted in acetone and absorbance was recorded in a spectrophotometer $(503 \mathrm{~nm})$ by using petroleum ether as blank.

Estimation of total soluble phenolics: The plant material was extracted by dipping in absolute methanol for one week. The methanol extract was determined through rotary evaporator. The phenolic contents were examined through folin ciocalteau phenol reagent method according to the description of (Chaovanalikit and Wrolstad, 2004; Iftikhar et al., 2011).

Estimation of Starch: Accumulations of starch contents in plant leaves and roots play an important role of virus infections on host plant. Therefore, starch contents were observed by Iodo-starch test (Iftikhar et al., 2015) for quick indexing used in citrus for both virus and viruslike diseases. Tomato leaf curl virus infected leaves and healthy leaves were immersed in iodine solution for about 1.5-2 minutes followed by washing with distill water. The edges of leaf samples at advancing margins were examined for dark staining by using magnifying glass.

Correlation of Environmental Factors: Environmental factors were recorded fortnightly from In-service Agriculture Institute Sargodha. Factors included maximum and minimum temperature and relative humidity.

\section{STATISTICAL ANALYSIS}

The data was correlated in relation to various environmental factors by using " $R$ " software.

\section{RESULTS}

Correlation of physiological parameters with environmental factors: Physiological parameters viz; chlorophyll contents, lycopene determination, photosynthesis rate, starch contents and total soluble phenolic contents were observed and correlated with the environmental factors.

Correlation of chlorophyll contents with environmental factors: Chlorophyll contents of leaves (healthy and infected) were compared. Chlorophyll contents in virus infected leaves decreased significantly as compared to healthy leaves. Maximum temperature has negative correlation with healthy and infected leaves. No changes in chlorophyll contents of infected leaves have been observed in minimum temperature (Figure 1A) whereas it showed negative correlation with healthy leaves (Figure 1B). Chlorophyll contents of infected leaves showed a positive correlation with relative humidity. Chlorophyll were directly proportional to an increase in relative humidity but no significant effect was observed in plants infected with TLCV (Figure 1B).

Relationship of photosynthesis rate with environmental factors: Photosynthetic rate was measured with the help of IRGA. Photosynthesis rate increased as temperature increased in case of infected plants. At minimum temperature photosynthesis rate also increased in infected plants whereas it decreased in healthy plants and same in the case of relative humidity for both infected and healthy plants (Figure 2). 


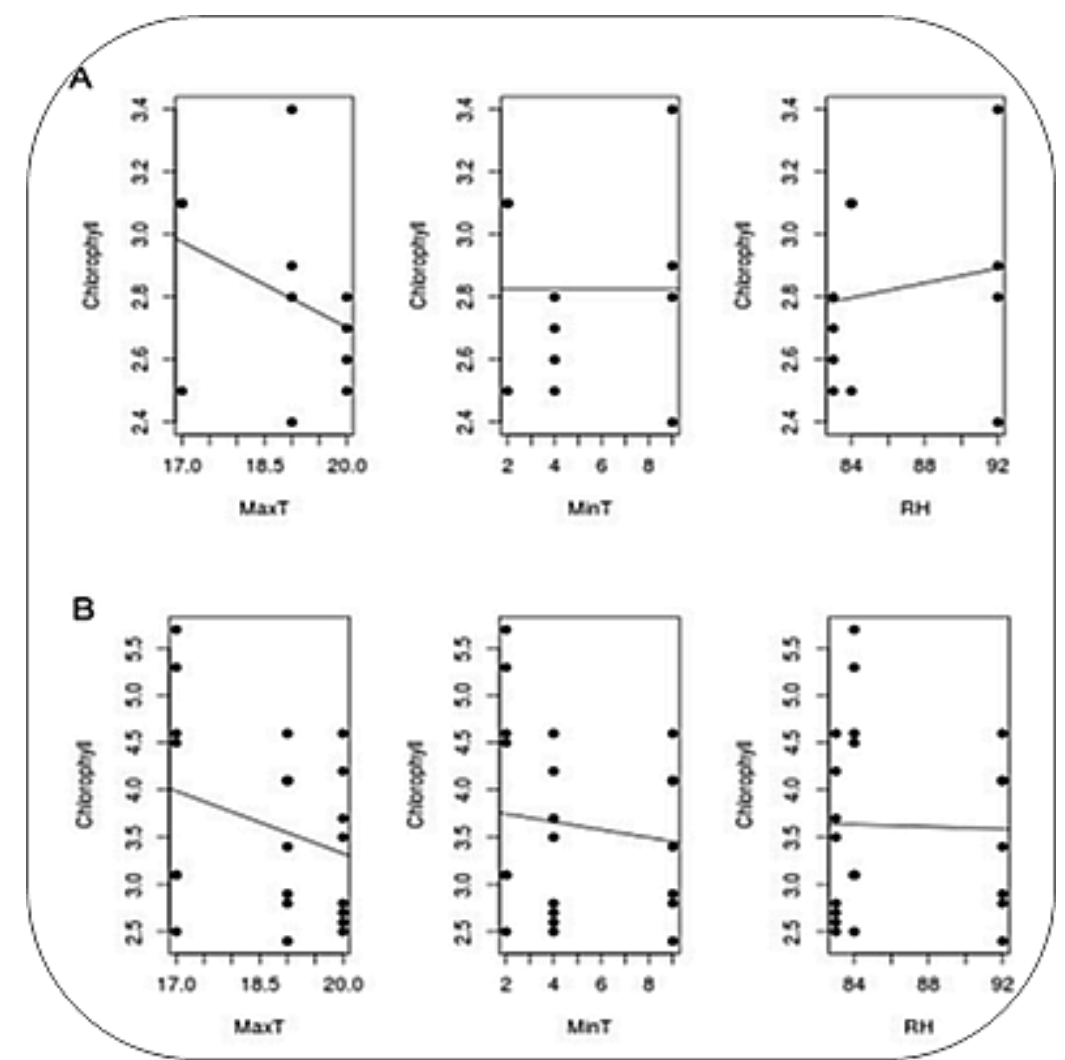

Figure 1. Chlorophyll contents of infected leaves (A) and healthy leaves (B)
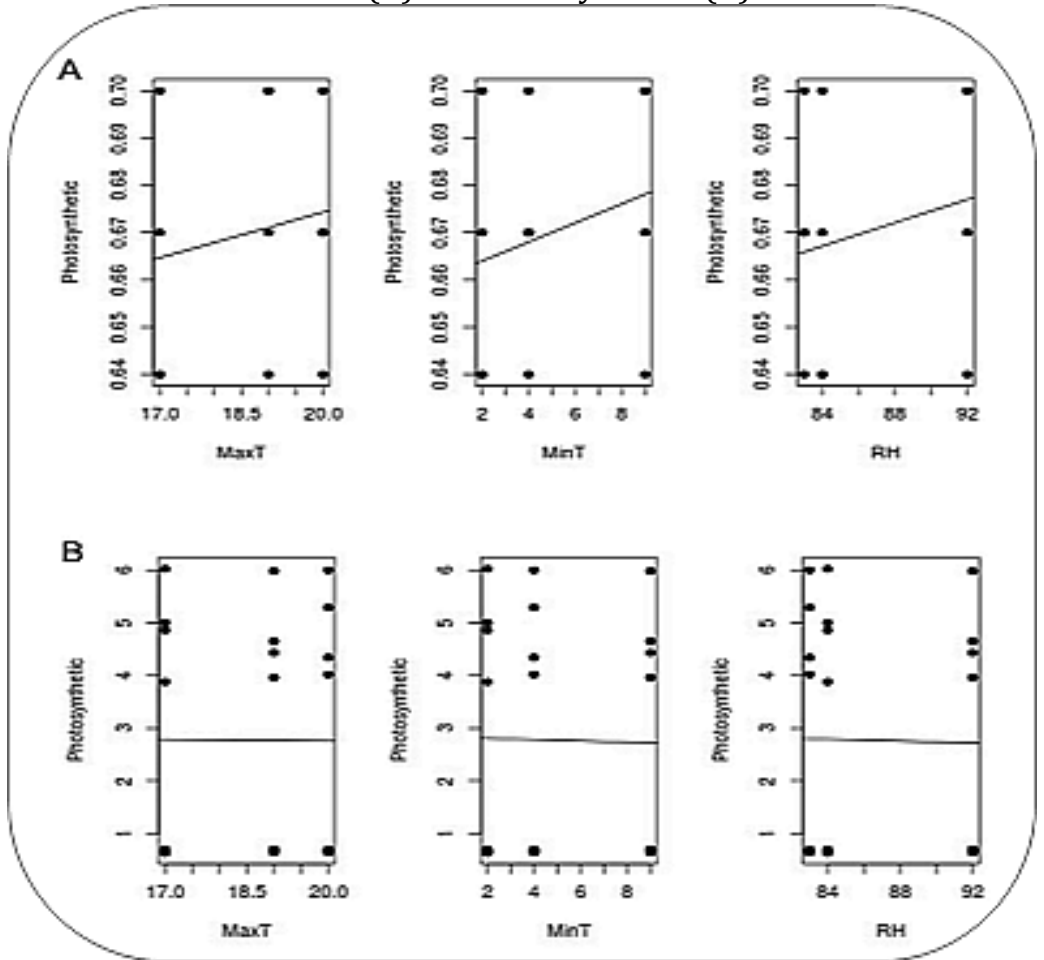

Figure 2. Photosynthetic rate of infected leaves (A) and healthy leaves (B)

Relationship of lycopene with environmental parameters (max temp,minimum temp, relative factors: Lycopene contents showed a negative humidity) for both infected as well as healthy plants corelation as its rate decreased at all enviornmenatal (Figure 3). 


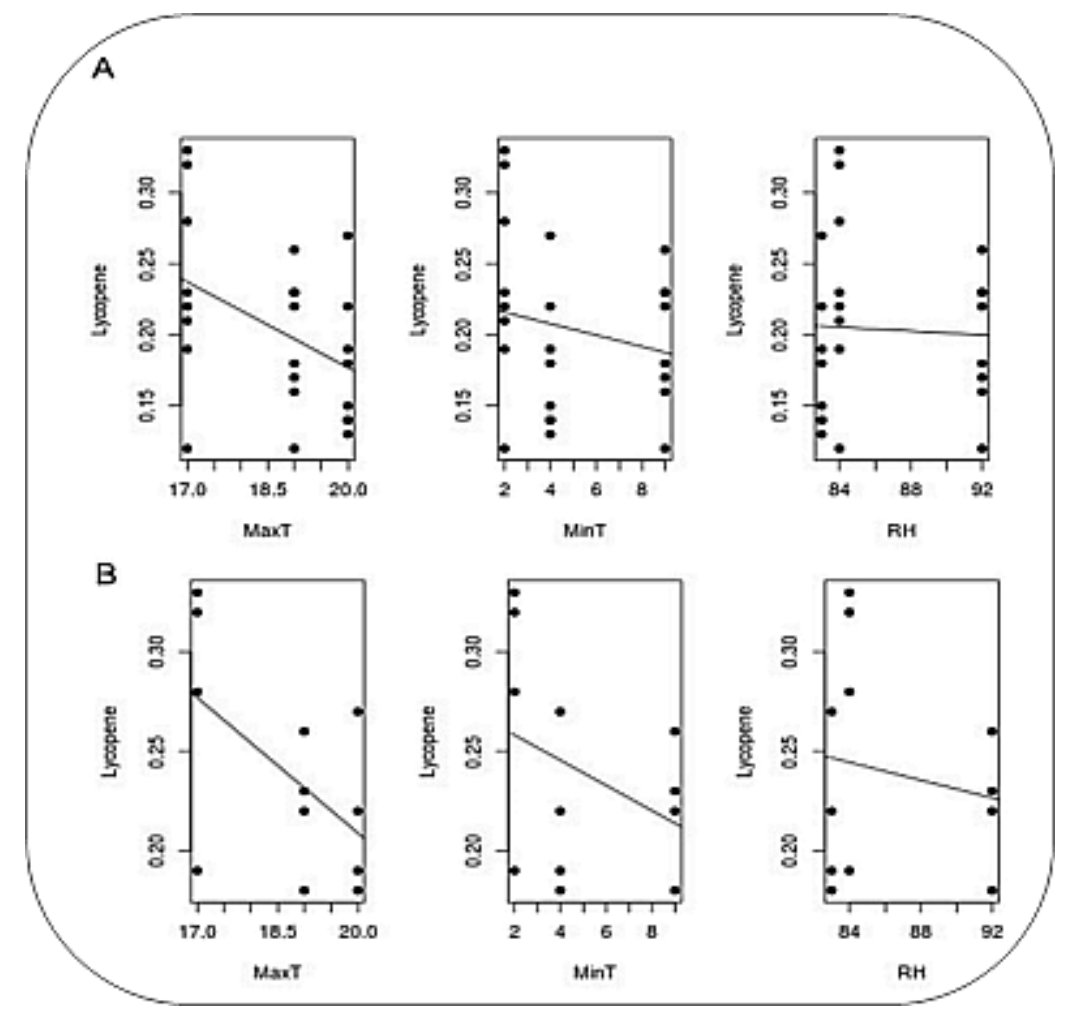

Figure 3. Lycopene contents of infected leaves (A) and healthy leaves (B)

Correlation of phenolic with environmental temperature in case of infected plants increased factors: Phenolic contents of leaves viz; healthy and whereas for both other factors it is negatively infected were calculated and it was obvious from correlated for both infected and healthy plants investigation that phenolic compound at maximum (Figure 4).

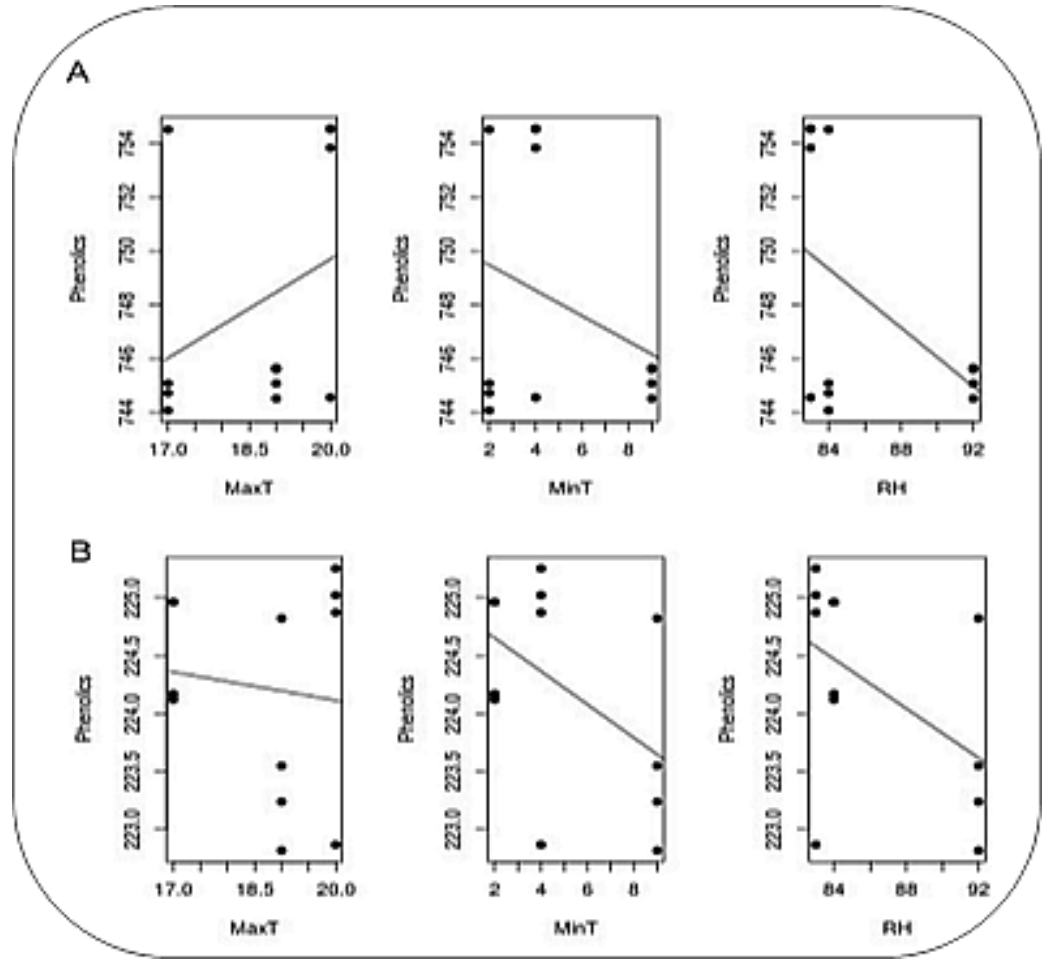

Figure 4. Phenolic contents of infected leaves (A) and healthy leaves (B) 
Starch content: Healthy leaves showed no color while infected leaves showed dark grey to black stains after Table 1 . Starch contents of healthy and infected leaves

\begin{tabular}{cccc}
\hline Healthy Sample & Reaction & Infected Sample & Reaction \\
\hline 1 & $-\mathrm{VE}$ & 1 & $+\mathrm{VE}$ \\
\hline 2 & $-\mathrm{VE}$ & 2 & $+\mathrm{VE}$ \\
\hline 3 & $-\mathrm{VE}$ & 3 & $+\mathrm{VE}$ \\
\hline 4 & $-\mathrm{VE}$ & 4 & $+\mathrm{VE}$ \\
\hline 5 & $-\mathrm{VE}$ & 5 & $+\mathrm{VE}$ \\
\hline 6 & $-\mathrm{VE}$ & 6 & $+\mathrm{VE}$ \\
\hline 7 & $-\mathrm{VE}$ & 7 & $+\mathrm{VE}$ \\
\hline 8 & $-\mathrm{VE}$ & 8 & $+\mathrm{VE}$ \\
\hline 9 & $-\mathrm{VE}$ & 9 & $+\mathrm{VE}$ \\
\hline 10 & $-\mathrm{VE}$ & 10 & $+\mathrm{VE}$ \\
\hline
\end{tabular}

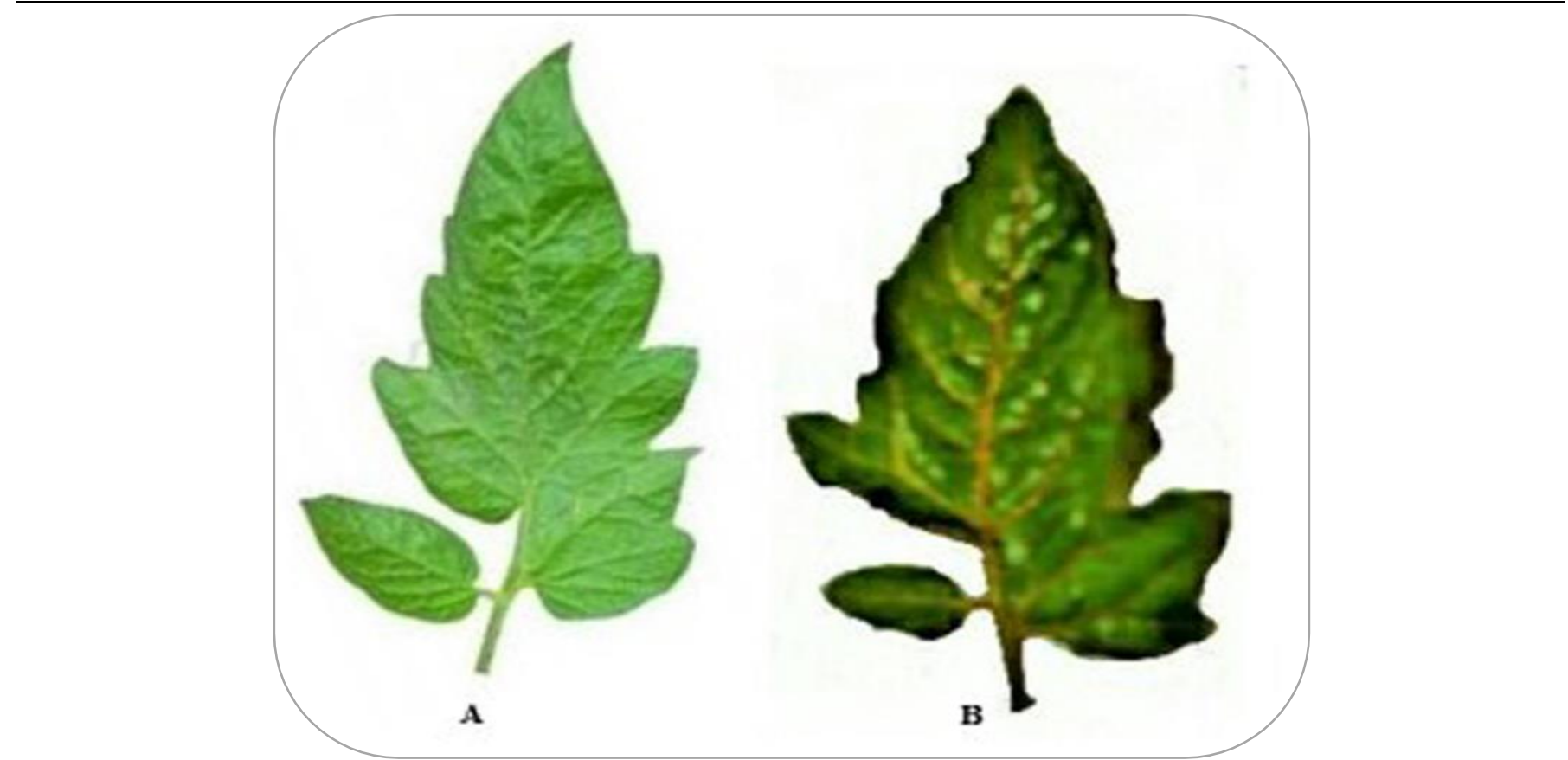

immersed in iodine and reactions were observed negative and positive respectively (Table. 1 and Figure 5).

Figure 5. Healthy tomato leaf (A) and infected tomato leaf (B).

\section{DISCUSSION}

Tomato leaf curl virus is the most destructive disease resulted in severe crop losses across the world and prime limiting aspect in production of tomato in Pakistan which approximately caused $30-40 \%$ yield losses (Tariq, 1999). Tomato leaf curl virus spread from one place to other via a vector called White fly (Bemesia tabacii) and cause huge destruction both qualitatively and quantitatively (Sánchez-Campos et al., 2013). Keeping in view the spread and severity of TLCV disease, the present study was planned to investigate different physiological parameters in relation to various environmental factors.

Physiological parameters and metabolic activities of the host plant considerably influenced by the attack of the disease. The biochemical changes caused due to morphological variations and the degree of yield loss can be observed by apparent symptoms caused by infected plant (Levy and Marco, 1982). Khalil et al., (2014) reported that virus infected tomato plants caused considerable decrease in total of soluble sugar; insoluble sugar and carbohydrate contents in stem and plant leaves respectively as compared with control. Tomato yellow leaf curl virus causes definite changes in physiological functions of virus infected plants resulted in reduction of the main components of the plant viz; Plant growth, photosynthetic pigments, total carbohydrate contents and $\mathrm{Mg++}$ ions.

Viruses are directly accountable for degradation of chlorophyll contents in virus infected plants. Bertamini 
et al., (2002) and Hemida (2005) observed almost similar outcomes with our findings that chlorophyll contents of virus infected leaves were found to be reduced at maximum temperature. Our experimental results are also comparable with Singh et al., (2014) who investigated that occurrence of TLCV has a significant effect on chlorophyll concentration in infected host plant which exhibit very close association among susceptible and resistant genotypes. Chlorophyll concentration reduced in infected virus plants at high temperature has been studied many scientists which might be due to chlorosis which are more frequently occurred in the infected leaves. Our results were also in line with the findings of Marco (1975) who examined that interveinal chlorosis is the one of the most obvious symptoms expressed by virus infected host plants.

Contrary to results of Bertamini et al., (2004) who confirmed the photosynthetic level in virus infected tomato plants generally reduced as compared to healthy plants whereas in our study we observed that Photosynthetic rate has been increased after the attack of virus as compared to healthy plants which might be due to different environmental factors and geographical distribution of the viruses across the world. The lycopene contents reduced in both viruses infected as well as in healthy fruits. Our results were in accordance with Paranita et al., (2012) who investigated that lycopene contents of virus infected fruits were reducing after attack while Akanda et al., (1998) reported that the level at which chlorophyll contents, $\beta$ carotene and lycopene contents reduced significantly depends upon virus infected tomato plants. The max. temperature showed positive association while mini. temperature and relative humidity showed negative correlation with phenolic contents in virus infected tomato leaves. The similar findings have been reported by several researchers (Kumar et al., 2010; Raj et al., 2005; Huang and Backhouse, 2005).

\section{CONCLUSION AND RECOMMENDATION}

Chlorophyll contents showed a declining trend in virus infected leaves. Maximum temperature had no significant impact on healthy and infected leaves, whereas minimum temperature has only impact on healthy leaves. Relative humidity increased the Chlorophyll contents of infected leaves. Maximum temperature increased the photosynthetic rate of infected plants. At minimum temperature photosynthetic rate was increased in infected plants whereas it little bit decreases in healthy plants and same in case of relative humidity for both infected and healthy plants. Lycopene contents (infected and healthy Plants) decresed if enviornmenatal factors incresed. Maximum temperature increased the phenolic compound in infected plants whereas both other factors (minimum temperature \& relative humidity) decreased phenolic compound in both infected and healthy plants. Healthy leaves showed no color while infected leaves showed dark grey to black stains after immersed in iodine and reactions were observed as negative and positive. Therefore, it is recommended study of environmental factors in relation to physiological functions of plants in future will not only be helpful in determining the response against plant diseases but also for monitoring the progression of disease.

\section{REFERENCES}

Agarwal, S. and A. V. Rao. 2000. Tomato lycopene and its role in human health and chronic diseases. Canadian Medical Association journal 163: 739-744.

Akanda, A., N. Alam, A. Khair and A. Muqit. 1998. Altered metabolism of tomato leaves due to Cucumber mosaic virus. Bangladesh Journal of Scientific Research, 16: 1-6.

Arooj, S., Y. Iftikhar, M. Kamran, M. I. Ullah, M. Mubeen, Q. Shakeel, N. Zeerak and I. Bilqees. 2017. Management of tomato leaf curl virus through non-chemicals in relation to environmental factors. Pakistan Journal of Phytopathology, 29: 41.

Bertamini, M., K. Muthuchelian and N. Nedunchezhian. 2004. Effect of Grapevine Leafroll on the Photosynthesis of Field Grown Grapevine Plants (Vitis vinifera L. cv. Lagrein). Journal of Phytopathology, 152: 145-152.

Bertamini, M., M. S. Grando, K. Muthuchelian and N. Nedunchezhian. 2002. Effect of phytoplasmal infection on photosystem II efficiency and thylakoid membrane protein changes in field grown apple (Malus pumila) leaves. Physiological and Molecular Plant Pathology, 61: 349-356.

Chaovanalikit, A. and R. E. Wrolstad. 2004. Total Anthocyanins and Total Phenolics of Fresh and Processed Cherries and Their Antioxidant Properties. Journal of Food Science, 69: FCT67-FCT72.

Gottlieb, Y., E. Zchori-Fein, N. Mozes-Daube, S. Kontsedalov, M. Skaljac, M. Brumin, I. Sobol, H. Czosnek, F. Vavre and F. Fleury. 2010. The transmission efficiency of tomato yellow leaf curl virus by the whitefly Bemisia tabaci is correlated with the presence of a specific 
symbiotic bacterium species. Journal of virology, 84 : 9310-9317.

Green, S. 1994. Leaf curl and yellowing viruses of pepper and tomato an overview. Asian Vegetable Research \& Development Center.

Hanssen, I. M., M. Lapidot and B. P. H. J. Thomma. 2010. Emerging Viral Diseases of Tomato Crops. Molecular Plant-Microbe Interactions, 23: 539-548.

Hasegawa, P. M., R. A. Bressan, J.-K. Zhu and H. J. Bohnert. 2000. Plant cellular and molecular responses through salinity. Annual Review of Plant Physiology and Plant Molecular Biology, 51: 463-499.

Hemida, S. 2005. Effect of bean yellow mosaic virus on physiological parameters of Vicia faba and Phaseolus vulgaris. International Journal of Agriculture and Biology (Pakistan).

Huang, L. D. and D. Backhouse. 2005. Induction of defence responses in roots and mesocotyls of sorghum seedlings by inoculation with Fusarium thapsinum and F. proliferatum, wounding and light. Journal of Phytopathology, 153: 522-529.

Iftikhar, Y., S. A. Khan, M. J. Jaskani and R. M. S. Tariq. 2015. Quick indexing of Huanglongbing on the basis of symptomology and iodo-starch test in relation to environmental factors. Pakistan Journal of Agricultural Sciences, 52.

Iftikhar, Y., S. Mughal, M. Khan, M. Khan, A. Batool, S. Naqvi and SamiUllah. 2011. Some biochemical changes in tristeza infected citrus trees in Pakistan. International Journal of Science and Nature, 2: 621-624.

Khalil, R., F. Bassiouny, K. El-Dougdoug, S. Abo-Elmaty and M. Yousef. 2014. A dramatic physiological and anatomical changes of tomato plants infecting with tomato yellow leaf curl germinivirus. International Journal of Agricultural Sustainability, 10: 1213-1229.

Kumar, V., C. S. Yadav, S. Singh, S. Goel, R. S. Ahmed, S. Gupta, R. K. Grover and B. D. Banerjee. 2010. CYP $1 \mathrm{~A} 1$ polymorphism and organochlorine pesticides levels in the etiology of prostate cancer. Chemosphere, 81: 464-468.

Levy, M. 1982. Controlled performance heat exchanger for evaporative and condensing processes. United States Patent, 4: 114-340

Marco, S. 1975. Chlorophyll content of tomato yellow leaf curl virus-infected tomatoes in relation to virus resistance. Phytoparasitica, 3: 141-144.
Melzer, M. J., D. Y. Ogata, S. K. Fukuda, R. Shimabuku, W. B. Borth, D. M. Sether and J. S. Hu. 2010. First Report of Tomato yellow leaf curl virus in Hawaii. Plant Disease, 94: 641-641.

Mubeen, M., Y. Iftikhar, M. I. Ullah, Q. Shakeel, M. Aatif and I. Bilqees. 2017. Incidence of Okra Yellow Vein Mosaic Disease in Relation to Insect Vector and Environmental Factors. Environment \& Ecology, 35: 2215-2220.

Mughal, S. 1985. Viral diseases of tomato and their control. Progressive Farming (Pakistan). Food and Agriculture Organization of the United Nations. 5: 20-23.

Paranita, A. 2012. Implementasi model pembelajaran terpadu tipe integrated pada pembelajaran seni budaya di SD. Versi Elektronik). Diunduh pada tanggal, 18.

Raj, S., R. Singh, S. Pandey and B. Singh. 2005. Agrobacteriummediated tomato transformation and regeneration of transgenic lines expressing Tomato leaf curl virus coat protein gene for resistance against TLCV infection. Current science: 1674-1679.

Rangana, S., 1979. Manual Analysis of fruit and vegetable products. Tata McGrow Hill pub.Co. Ltd. New Delhi, 363.

Sánchez-Campos, S., A. Martínez-Ayala, B. Márquez-Martín, L. Aragón-Caballero, J. Navas-Castillo and E. Moriones. 2013. Fulfilling Koch's postulates confirms the monopartite nature of tomato leaf deformation virus: A begomovirus native to the New World. Virus Research, 173: 286-293.

Singh, R. K., N. Rai, M. Singh, S. N. Singh and K. Srivastava. 2014. Selection of tomato genotypes resistant to tomato leaf curl virus disease using biochemical and physiological markers. The Journal of Agricultural Science, 153: 646-655.

Tajul, M., K. Naher, T. Hossain, Y. Siddiqui and M. Sariah. 2011. Tomato yellow leaf curl virus (TYLCV) alters the phytochemical constituents in tomato fruits. Australian Journal of Crop Science, 5: 575.

Tariq, M. 1999. Molecular identification of tomato leaf curl virus in Pakistan and development of transgenic resistance in a model system. Journal of Asian and African studies, 11: 44-52.

Wobbes, B. 2004. Control of plant carbohydrate partitioning by the Arabidopsis thaliana ATB2 bZIP transcription factor gene. 